\title{
Haematological and histopathological analysis in South American fish Piaractus mesopotamicus parasitized by monogenean (Dactylogyridae)
}

\author{
Jerônimo, GT. ${ }^{*}$, Pádua, SB. ${ }^{b}$, Bampi, D. ${ }^{a}$, Gonçalves, ELT ${ }^{a}$, Garcia, P. $^{a}$, \\ Ishikawa, MM. ${ }^{c}$ and Martins, $M L .^{a}$ \\ ${ }^{a} A Q U O S$ - Aquatic Organisms Health Laboratory, Aquaculture Department, Federal University of Santa Catarina - UFSC, \\ Rod. Admar Gonzaga, 1346, CEP 88040-900, Florianópolis, SC, Brazil \\ bAquivet Saúde Aquática, Rua Antonio Ernesto Célico, 359, Quadra 8, Lote 16, Residencial Marcia Damha III, \\ CEP 15061-810, São José do Rio Preto, SP, Brazil \\ 'Embrapa Environment, Brazilian Agricultural Research Corporation (EMBRAPA), Rod. SP 340, \\ Km 127,5, Caixa Postal 69, CEP: 13820-000, Jaguariúna, SP, Brazil \\ *e-mail: gabrielatj@gmail.com
}

Received: June 10, 2013 - Accepted: July 15, 2013

(With 3 figures)

\begin{abstract}
Monogeneans are the parasites mostly found on the body surface and gills of fish and can cause large losses in farmed fish. Some studies demonstrate elevated parasitic levels causing hematological alterations. But few of them relate the effects of parasitism on the hematology and histopathology of native freshwater farmed fish. This study evaluated the host-parasite relationship in pacu (Piaractus mesopotamicus) parasitized by the monogenean Anacanthorus penilabiatus. Hematological and parasitological assessments were obtained in 60 fish captured in a fish farm located in Dourados, State of Mato Grosso do Sul, Central Brazil. Fish were analyzed in different categories of parasite number: class I ( $\mathrm{n}=13 ; 0-200$ parasites), class II ( $\mathrm{n}=17$; 201-1200 parasites); class III ( $\mathrm{n}=7$; 1201-2200 parasites); and class IV $(\mathrm{n}=23$; more than 2200 parasites per host). The highest levels of parasitism caused significant decrease $(\mathrm{p}<0.05)$ in the hematocrit, red blood cells (RBC), mean hemoglobin concentration (MCHC) and basophils number. Thrombocytes, mean corpuscular volume (MCV), mean corpuscular hemoglobin concentration (MCHC), monocytes, eosinophils, neutrophils and LG-PAS did not present significant difference among the parasitic levels. In contrast, increased number of total leukocytes and lymphocytes were found in highly-parasitized fish. A positive linear correlation $(p<0.01)$ was found between the amount of parasites and fish weight. Histopathology revealed severe hyperplasia, sub-epithelial edema, fusion of the secondary lamellae, focal and multifocal necrosis in highly parasitized fish.
\end{abstract}

Keywords: Pacu, fish farm, parasitism, haematology, histology.

\section{Análises hematológica e histopatológica no peixe sul-americano Piaractus mesopotamicus parasitado por Monogenea (Dactylogyridae)}

\section{Resumo}

Parasitos Monogenea são principalmente encontrados na superfície corporal e brânquias dos peixes, e podem acarretar grandes perdas em pisciculturas. Alguns estudos demonstram que elevados níveis de infestação parasitária podem alterar os parâmetros sanguíneos. Porém, poucos estudos se direcionam a esclarecer os efeitos do parasitismo sobre as características hematológicas em peixes nativos. Este estudo avaliou a relação parasito-hospedeiro em pacu (Piaractus mesopotamicus) parasitado pelo monogenético Anacanthorus penilabiatus. Avaliações hematológicas e parasitológicas foram obtidas de 60 peixes capturados de uma piscicultura localizada em Dourados, Estado de Mato Grosso do Sul (MS), Brasil Central. Os peixes foram divididos em diferentes categorias de número de parasitos: classe I ( $\mathrm{n}=13 ; 0$-200 parasitos), classe II ( $\mathrm{n}=17 ; 201-1200$ parasitos); classe III ( $\mathrm{n}=7 ; 1201-2200$ parasitos); e classe IV ( $\mathrm{n}=23$; mais que 2200 parasitos por hospedeiro). Os níveis mais elevados de parasitismo causaram diminuição significativa $(\mathrm{p}<0.05)$ no hematócrito, eritrócitos $(\mathrm{RBC})$, concentração de hemoglobina corpuscular média $(\mathrm{CHCM})$ e número de basófilos. Trombócitos, volume corpuscular médio (VCM), concentração de hemoglobina corpuscular media (CHCM), monócitos, eosinófilos, neutrófilos e LG-AS não apresentaram diferença significativa entre os níveis de parasitismo. Em contraste, o aumento do número de leucócitos totais e linfócitos foram encontrados em peixes altamente parasitados. Houve correlação linear positiva entre a quantidade de parasitos e o peso dos peixes. O exame histopatológico revelou severa hiperplasia, edema sub-epitelial, fusão das lamelas secundárias, necroses focal e multifocal em peixes altamente parasitados.

Palavras-chave: Pacu, piscicultura, parasitismo, hematologia, histologia 


\section{Introduction}

Piaractus mesopotamicus Holmberg, 1887, commonly named "pacu" is abundant in the Brazilian rivers distributed on several regions of the Plata Basin. It is of great importance for aquaculture, fishing and sport fishing in its original region (Zaniboni-Filho, 2004). It is one of the most studied fish species because of its economic importance to West-Central and Southeastern Brazil. According to data of Ministry of Fisheries and Aquaculture (Brasil, 2010), in Brazil in 2010 , an increase of $35 \%$ in the pacu production was observed compared to 2008. By the way, the aquaculture development implies in intensive production system, which can lead to water quality problems, inadequate feeding, and infectious and parasitic diseases that cause significant economic losses (Jerônimo et al., 2011).

Severe parasitic infestations constitute the most important obstacle to fish farming, leading to epizootic outbreaks (Khan, 2009); however, they may introduce new pathogens that affect the native population (Krkosek et al., 2006). The importance of disease impact in the hosts must be emphasized, once it contributes to elaborate strategies for control and therapeutic in fish culture.

In Brazil, the monogeneans are one of the most important fish parasites (Martins et al., 2002), being found both as ecto and endoparasites (Jerônimo et al., 2010). The host-parasite relationship is little studied and the monogeneans have different strategies of attachment on the hosts as well as their reproductive mechanisms, in which they may influence on their pathogenicity. Studies demonstrated that monogenean infestation have caused epithelial (Hirazawa et al., 2010), gill (Del Rio-Zaragoza et al., 2010) and hematological alterations (Tavares-Dias et al., 2008; Araújo et al., 2009; Del Rio-Zaragoza et al., 2010), consequently favoring secondary infections (Xu et al., 2007).

This study evaluated the host-parasite relationship in pacu, P. mesopotamicus, parasitized by Anacanthorus penilabiatus Boeger, Husack and Martins, 1995. The effects of monogenean infestation were evaluated by season and histopathology and hematology in different classes of parasite number.

\section{Material and Methods}

In July (Cold Season) and October (Hot Season) 2009, 60 fish, 30 in each season, were captured by nets in a semi-intensive fish farm situated in Dourados, MS, Central Brazil. After capture, the fish were immobilized in wet fabric for blood collection with syringes with a drop of EDTA 3\%, according to Ishikawa et al. (2010) and transported to the fish farm laboratory at 'Embrapa Agropecuaria Oeste' for parasitological analysis.

The blood samples were used for hematocrit percentage analysis (Goldenfarb et al. 1971), hemoglobin concentration by the method of Collier (1944), and erythrocyte number (RBC) counted in a Neubauer chamber in diluted blood $(1: 200)$ in citrate-formalin solution. Hematimetric parameters such as mean corpuscular volume (MCV) and mean corpuscular hemoglobin concentration $(\mathrm{MCHC})$ were obtained according to Wintrobe (1934). Total plasma protein was determined with a portable refractometer.

For total counting of leukocytes (WBC) and thrombocytes and differential counting of leukocytes, the blood smears were stained with May Grünwald-Giemsa-Wright (TavaresDias and Moraes, 2006).

After euthanized in clove oil $75 \mathrm{mg} . \mathrm{L}^{-1}$ (Ethic Commitee 23080.0 29979/2009-05/CEUA/UFSC), the gills were removed from the fish, bathed in hot water $60^{\circ} \mathrm{C}$ and fixed in 5\% formalin solution for quantification in Petri dishes. The parasitological indexes were calculated according to Bush et al. (1997). For identification, the parasites were mounted in Hoyer's medium to observe the sclerotized structures as suggested by Kritsky et al. (1995) and Boeger et al. (1995). Fish were divided in different categories of parasite number as follows: class I $(n=13$; 0-200 parasites), class II ( $\mathrm{n}-17$; 201-1200 parasites); class III $(n=7 ; 1201-2200$ parasites and class IV $(n=23$; more than 2200 parasites).

For histopathology, the gills from 20 fish (10 from each season) were fixed in buffered formalin solution, processed by usual histology techniques, embedded in paraffin for cross sections $(5 \mu \mathrm{m})$, and stained with hematoxylin-eosin.

The water quality parameters were measured during the month prior to fish collections, in cold and hot seasons, respectively: Water temperature $20.83 \pm 0.18 ; 24.96 \pm 0.36$, dissolved oxygen $5.90 \pm 0.96 ; 2.28 \pm 0.74$, electrical conductivity $60.74 \pm 5.11 ; 48.69 \pm 3.38$ and $\mathrm{pH}$ $7.29 \pm 0.18 ; 6.71 \pm 0.21$ were measured by multiparameter equipment $\mathrm{HANNA}^{\circledR}$; alkalinity $52.31 \pm 6.86 ; 64.47 \pm 5.82$ and hardness $30.62 \pm 2.28 ; 23.35 \pm 3.71$ were measured by the titration method; and ammonia $0.29 \pm 0.12 ; 0.63 \pm 0.23$ and iron $1.34 \pm 0.35 ; 0.72 \pm 0.19$ by the colorimetric method ALFAKIT ${ }^{\circledR}$.

The water quality data were submitted to Principal Component Analysis (PCA). In order to compare the amount of Monogenea between the seasons, the values were transformed in square root and submitted to variance analysis (ANOVA). The homoscedasticity was tested by the Barlett's test and the averages compared by Tukey's test. The hematological parameters were compared by the variance analysis (ANOVA). Data were transformed into square root and the percentages transformed in arcsin square root. The homoscedasticity was tested using Bartlett's test and the means compared by Tukey's test at significant level 0.05 .

\section{Results}

The parasites were identified as A. penilabiatus (Monogenea: Dactylogyridae). Prevalence was $100 \%$ in both seasons, but the mean intensity of parasites and mean abundance were significantly higher in the hot season than in the cold season $(\mathrm{p}<0.05)$ (Table 1$)$.

In the Principal Component Analysis (Figure 1), the representation of factors altogether corresponded to $88.05 \%$ of the variance. The results clearly showed stronger relation between the cold season and the elevated values 
of electrical conductivity, hardness, $\mathrm{pH}$, dissolved oxygen and iron. In contrast, the hot season was strongly correlated to ammonia, alkalinity and temperature.

Fish from classes III and IV, the most parasitized, presented the highest $(p<0.05)$ mean weight and length when compared to those from classes I and II, which presented 0 to 1200 parasites per host (Table 2). The parasitic infestation caused significant decrease $(\mathrm{p}<0.05)$ in the hematocrit and $\mathrm{RBC}$ in classes III and IV, as well as reduced hemoglobin concentration in fish from class IV, which were the most

Table 1. Parasitological indices of Piaractus mesopotamicus infested by Anacanthorus penilabiatus in cold and hot season.

\begin{tabular}{lcc}
\hline & Cold Season & Hot Season \\
\hline Prevalence (\%) & 100 & 100 \\
Mean Intensity & $316.3 \pm 282.1^{\mathrm{b}}$ & $2742.3 \pm 615.0^{\mathrm{a}}$ \\
Mean Abundance & $316.3 \pm 282.1^{\mathrm{b}}$ & $2742.3 \pm 615.0^{\mathrm{a}}$ \\
Variation & $(24-1113)$ & $(1979-4269)$ \\
\hline
\end{tabular}

Different letters indicate significant difference among seasons.

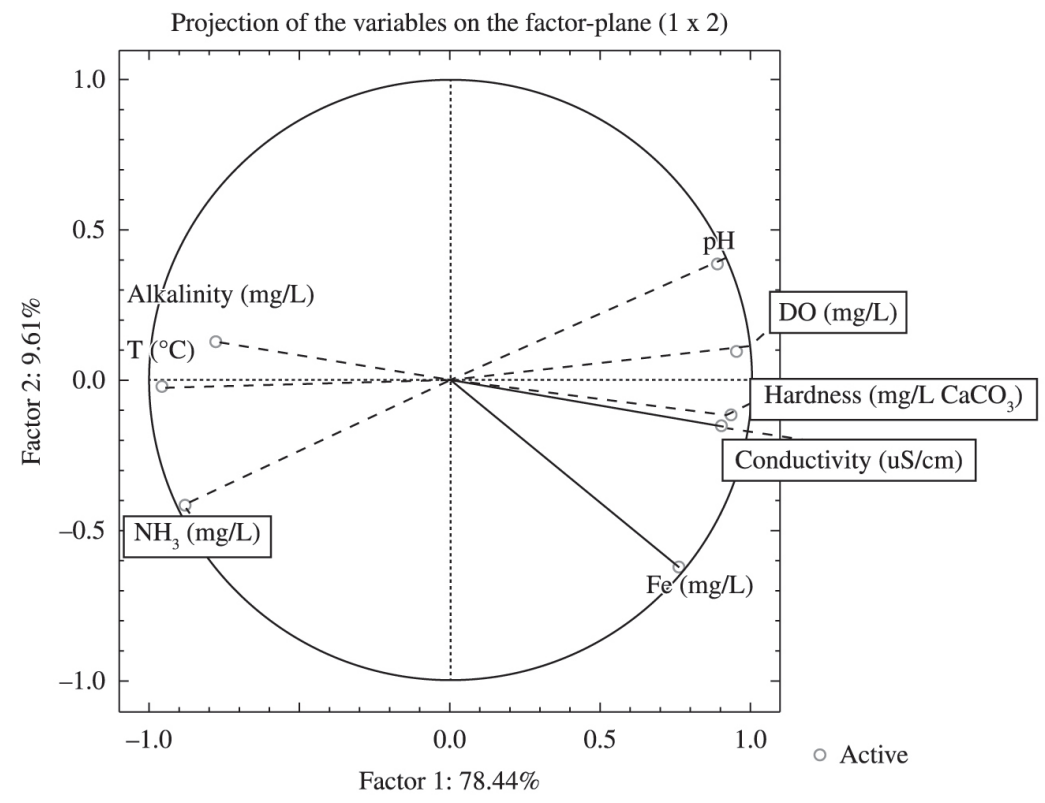

Projection of the cases on the factor-plane $(1 \times 2)$

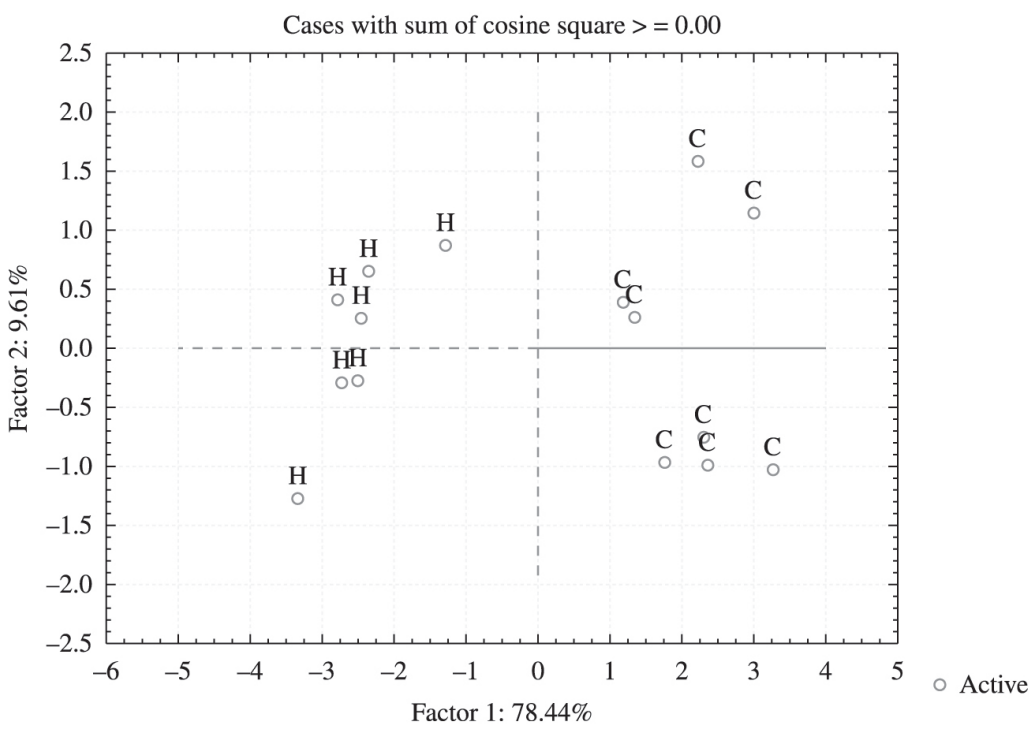

Figure 1. Principal component analysis (PCA) of water quality in cold season (C), and hot season (H). 
parasitized ones (Table 2$)$. Decreased $(p<0.05)$ number of basophils was also found in fish from classes III and IV. On the other hand, an increase in the WBC followed by increased $(p<0.05)$ number of lymphocytes were observed in fish from classes III and IV (Table 3). Thrombocytes, MCV, MCHC, monocytes, eosinophils, neutrophils and LG-PAS did not show significant difference among the classes of parasitism (Tables 2-3). Positive linear correlation $(p<0.01)$ was found between the number of parasites and fish weight (Figure 2).

Fish from classes I and II showed severe hyperplasia, as well as multifocal necrosis. On the other hand, fish from classes III and IV presented monogeneans attached on the gill lamellae. Perforated gill filaments were observed as a result of haptor attachment and epithelial perforation and dislodged tissue (Figure 3A) and loss of linear structure of the gill lamellae (Figure 3B). Other alterations such as displacement of basal interlamellar epithelium, hypertrophy of goblet and chloride cells, focal and multifocal hyperplasia of interlamellar epithelium from slight to severe resulted in partial or total fusion of the secondary lamellae (Figure 3C, D). Sub-epithelial oedema on the gill filaments and secondary lamellae, focal and multifocal necrosis and basal telangiectasia were the most important alterations in parasitized fish from classes
III (1201-2200 parasites per host) and IV (more than 2200 parasites per host).

\section{Discussion}

This study showed that water temperature, alkalinity and ammonia were strongly correlated to the hot season, which could explain the highest parasitic index by A. penilabiatus. Similarly to the present study, increased number of monogenean was also reported by Tavares-Dias et al. (2001), Martins et al. (2002), Schalch and Moraes (2005) and Schalch et al. (2006) in fish from free fishing systems in spring and summer in Southeastern Brazil. The authors argued that these situations were favored by high water temperature and culture conditions. Our results showed the highest mean intensity and mean abundance in the hot season. Not only the water temperature, but also an increase in the ammonia levels and a decrease in the dissolved oxygen could have stressed the fishes

This study showed significant blood alterations as a result of monogenean parasitism in freshwater native reared fish $P$. mesopotamicus. The most parasitized were the largest fish from classes III and IV. Contrarily to that observed in the present study, Del Rio-Zaragoza et al. (2010) did not find blood alterations in Lutjanus guttatus Steindachner, 1869 , parasitized by dactylogyrids in low, moderate and high

Table 2. Biometric parameters, erythrogram and total plasma protein in Piaractus mesopotamicus parasitized by different parasitic classes in Anacanthorus penilabiatus.

\begin{tabular}{lcccc}
\hline \multicolumn{1}{c}{ Parameters } & Class I & Class II & Class III & Class IV \\
\hline Weight $(\mathrm{g})$ & $492.6 \pm 191.1^{\mathrm{b}}$ & $410.1 \pm 109.9^{\mathrm{b}}$ & $929.9 \pm 199.8^{\mathrm{a}}$ & $932.8 \pm 162.2^{\mathrm{a}}$ \\
Length $(\mathrm{cm})$ & $26.6 \pm 2.8^{\mathrm{b}}$ & $25.4 \pm 2.5^{\mathrm{b}}$ & $32.6 \pm 1.8^{\mathrm{a}}$ & $31.4 \pm 2.1^{\mathrm{a}}$ \\
Hematocrit $(\%)$ & $33.2 \pm 2.7^{\mathrm{c}}$ & $33.3 \pm 2.9^{\mathrm{c}}$ & $29.0 \pm 3.3^{\mathrm{b}}$ & $31.1 \pm 3.0^{\mathrm{a}}$ \\
Erythrocytes $(\mathrm{RBC})\left(\mathrm{x} 10^{6} \cdot \mu \mathrm{L}^{\mathrm{b}}\right)$ & $1.7 \pm 0.1^{\mathrm{a}}$ & $1.7 \pm 0.2^{\mathrm{a}}$ & $1.2 \pm 0.2^{\mathrm{b}}$ & $1.3 \pm 0.2^{\mathrm{b}}$ \\
Hemoglobin $\left(\mathrm{g} \cdot \mathrm{dL}^{-1}\right)$ & $7.9 \pm 0.5^{\mathrm{a}}$ & $7.7 \pm 0.7^{\mathrm{a}}$ & $7.1 \pm 0.6^{\mathrm{ab}}$ & $7.1 \pm 0.8^{\mathrm{b}}$ \\
MCV $\left(\mathrm{g} \cdot \mathrm{dL}^{-1}\right)$ & $199.6 \pm 8.2^{\mathrm{a}}$ & $200.2 \pm 13.3^{\mathrm{a}}$ & $239.9 \pm 13.3^{\mathrm{a}}$ & $236.7 \pm 20.2^{\mathrm{a}}$ \\
MCHC $\left(\mathrm{g} \cdot \mathrm{dL}^{-1}\right)$ & $23.7 \pm 1.0^{\mathrm{a}}$ & $23.1 \pm 1.2^{\mathrm{a}}$ & $24.5 \pm 1.1^{\mathrm{a}}$ & $22.7 \pm 2.1^{\mathrm{a}}$ \\
TPP $\left(\mathrm{g} \cdot \mathrm{L}^{-1}\right)$ & $4.9 \pm 0.4^{\mathrm{bc}}$ & $4.6 \pm 0.4^{\mathrm{c}}$ & $5.4 \pm 0.1^{\mathrm{a}}$ & $5.1 \pm 0.4^{\mathrm{ab}}$ \\
\hline
\end{tabular}

Different letters indicate significant difference among classes of parasistism; MCV: mean corpuscular volume, MCHC: mean corpuscular hemoglobin concentration, TPP: total plasma protein. Class I: 0-200; Class II: 201-1, 200; Class III: 1, 201-2, 200; Class IV: more than 2,200 parasites per host.

Table 3. Total numbers of leukocytes and thrombocytes and differential count of leukocytes in Piaractus mesopotamicus parasitized by different parasitic classes of Anacanthorus penilabiatus.

\begin{tabular}{|c|c|c|c|c|}
\hline Parameters & Class I & Class II & Class III & Class IV \\
\hline Leukocytes (WBC) $\left(\mathrm{x} 10^{3} \cdot \mu \mathrm{L}^{-1}\right)$ & $23.3 \pm 8.2^{\mathrm{b}}$ & $25.7 \pm 12.2^{\mathrm{ab}}$ & $34.0 \pm 10.7^{\mathrm{a}}$ & $48.6 \pm 18.9^{\mathrm{a}}$ \\
\hline Thrombocytes $\left(\times 10^{3} \cdot \mu \mathrm{L}^{-1}\right)$ & $30.8 \pm 9.4^{\mathrm{a}}$ & $28.2 \pm 9.2^{\mathrm{a}}$ & $24.9 \pm 0.6^{\mathrm{a}}$ & $30.4 \pm 10.1^{\mathrm{a}}$ \\
\hline Monocytes $\left(\mathrm{x} 10^{3} \cdot \mu \mathrm{L}^{-1}\right)$ & $0.9 \pm 0.4^{\mathrm{ab}}$ & $1.0 \pm 0.8^{\mathrm{a}}$ & $0.9 \pm 0.6^{\mathrm{ab}}$ & $1.0 \pm 0.9^{\mathrm{a}}$ \\
\hline Lymphocytes $\left(\mathrm{x} 10^{3} \cdot \mu \mathrm{L}^{-1}\right)$ & $20.1 \pm 7.3^{\mathrm{ab}}$ & $20.5 \pm 9.6^{\mathrm{b}}$ & $30.5 \pm 9.8^{\mathrm{a}}$ & $42.9 \pm 18.6^{\mathrm{a}}$ \\
\hline Basophils $\left(\mathrm{x} 10^{3} \cdot \mu \mathrm{L}^{-1}\right)$ & $0.1 \pm 0.1^{\mathrm{b}}$ & $0.3 \pm 0.3^{\mathrm{a}}$ & $0.0 \pm 0.0^{\mathrm{b}}$ & $0.0 \pm 0.0^{\mathrm{b}}$ \\
\hline Eosinophils $\left(\mathrm{x} 10^{3} \cdot \mu \mathrm{L}^{-1}\right)$ & $1.1 \pm 1.2^{\mathrm{a}}$ & $2.3 \pm 2.5^{\mathrm{a}}$ & $1.5 \pm 1.7^{\mathrm{a}}$ & $2.7 \pm 1.7^{\mathrm{a}}$ \\
\hline Neutrophils $\left(\mathrm{x} 10^{3} \cdot \mu \mathrm{L}^{-1}\right)$ & $0.3 \pm 0.4^{\mathrm{a}}$ & $0.3 \pm 0.4^{\mathrm{a}}$ & $0.8 \pm 0.5^{\mathrm{a}}$ & $1.1 \pm 1.1^{\mathrm{a}}$ \\
\hline LG-PAS* $\left(x 10^{3} \cdot \mu \mathrm{L}^{-1}\right)$ & $0.9 \pm 0.6^{\mathrm{a}}$ & $1.2 \pm 2.4^{\mathrm{a}}$ & $0.1 \pm 0.2^{\mathrm{a}}$ & $0.8 \pm 0.9^{\mathrm{a}}$ \\
\hline $\mathrm{LI}^{* *}\left(\mathrm{x} 10^{3} \cdot \mu \mathrm{L}^{-1}\right)$ & $0.1 \pm 0.1^{\mathrm{a}}$ & $0.2 \pm 0.3^{\mathrm{a}}$ & $0.3 \pm 0.4^{\mathrm{a}}$ & $0.1 \pm 0.3^{\mathrm{a}}$ \\
\hline
\end{tabular}

Different letters indicate significant difference among classes of parasistism; *Granular leukocyte PAS positive; **Imature leukocytes. Class I: 0-200; Class II: 201-1, 200; Class III: 1, 201-2,200; Class IV: more than 2,200 parasites per host. 
parasitic levels. Similarly, Chaves et al. (2006), observed low hemoglobin concentration in Trachinotus marginatus Cuvier, 1832, naturally parasitized by the monogenean Bicotylophora trachinoti Mac Callum, 1921. In contrast, these authors did not observe alterations in the hematocrit and RBC. In pirarucu, Arapaima gigas Schinz, 1882, parasitized by Dawestrema cycloancistroides Kritsky, Boeger \&Tatcher, 1985, and D. cicloancistrium Price \& Nowlin,

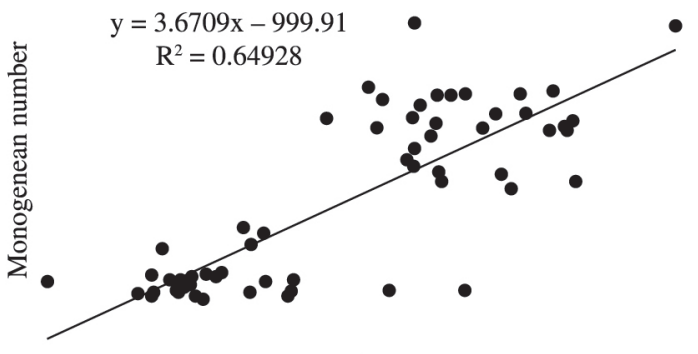

Weight (g)

Figure 2. Linear correlation between the number of Anacanthorus penilabiatus and weight of Piaractus mesopotamicus.
1967, (from 100 to 1534 parasites per host), Araújo et al. (2009) related higher values of hemoglobin concentration and MCHC. In the studies by Tavares-Dias et al. (2008), no variation on the hematological parameters were found in the same fish species $P$. mesopotamicus parasitized by $A$. penilabiatus, but no relation with mean intensity was found.

Hematological alterations might be related to physiological characteristics as well as disease or culture conditions. Moreover, in the host-parasite relationship, the severity in health alterations might be associated to attachment mechanisms of the parasite, its life cycle and, mainly, the number of parasites. No alterations described by Tavares-Dias et al. (2008) might be related to low parasite number. To date, in this study, fish from classes I and II (0 to 1200 parasites) have not presented hematological alterations.

The presence of monogenean in the gills causes increased mucus production and interferes on the respiratory function. One of the most important consequences in monogenean parasitism is the injury caused by the insertion of hooks and hooklets on the epithelium (Buchmann and Lindenstrøn, 2002)
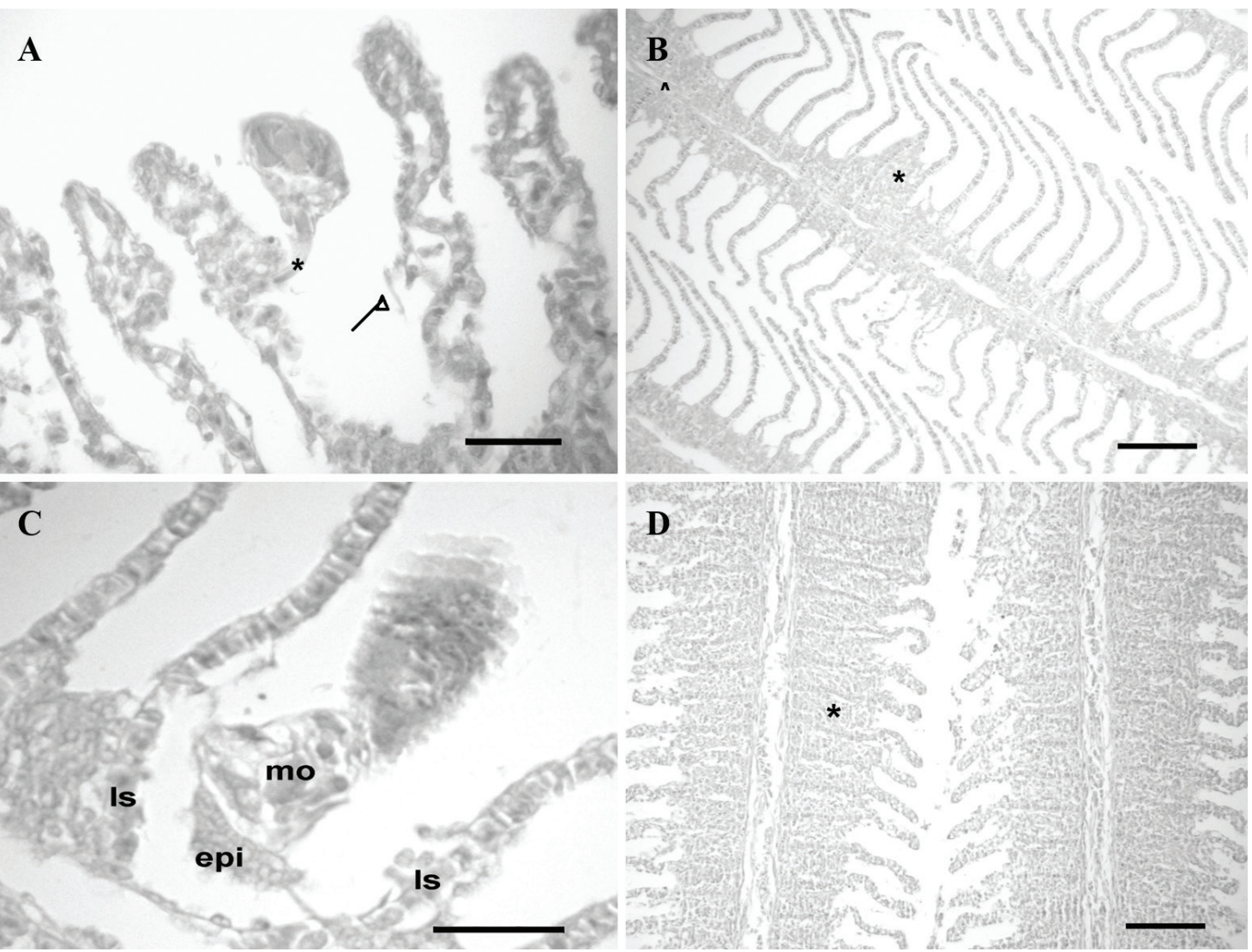

Figure 3. Photomicrographs of gill filaments of parasitized fish: A. Detail of epithelial tissue dislodged by the parasite hooks (*) $(\mathrm{HE}, \mathrm{Bar}=30 \mu \mathrm{m})$. B. Interlamellar epithelial hyperplasia with mild to partial melting $(*)$ of the secondary lamellae $(\mathrm{HE}, \mathrm{Bar}=100 \mu \mathrm{m})$. C. Monogenean fixed in the interlamellar tissue (epi), tearing the tissue; secondary lamellae (ls); monogenean $(\mathrm{mo})(\mathrm{HE}, \mathrm{Bar}=30 \mu \mathrm{m})$. D. Severe epithelial hyperplasia with total fusion $(*)$ of the secondary lamellae and epithelial proliferation $(\mathrm{HE}, \mathrm{Bar}=100 \mu \mathrm{m})$ 
associated to the parasite movement. This fact constitutes a gateway to local or systemic secondary infection. The injury by parasites associated with water quality could influence the host response, leading to multifocal necrosis observed in some gills. In addition, it can provoke inflammatory response with migration of thrombocytes, macrophages, lymphocytes and eosinophilic granulocytes that lead to hyperplasia of epithelial, goblet and chloride cells and, consequently, fusion of the secondary lamellae (Del RioZaragoza et al., 2010). As in the present study, alterations on the hematological parameters were also reported in other studies (Tavares-Dias et al., 2008; Araújo et al., 2009; Del Rio-Zaragoza et al., 2010). As a result of intense migration of leukocytes to the inflammatory site, improved release of cells from the hematopoietic centers occur (Satake et al., 2009), being possible to observe leukocytosis in diseased fish as found in fish from classes III and IV in this study, and also in naturally parasitized fish (Chaves et al., 2006; Araújo et al., 2009) or experimentally monogeneanparasitized fish (Chaves et al., 2006).

The largest fish generally have the capacity of tolerate larger numbers of parasites as proved in this study. Positive or negative correlation between the host length and monogenean parasitism may occur in fish (Lizama et al., 2007). This study showed that, in farming conditions, the largest fish may present larger amounts of monogenean in the gills and, consequently, could become more susceptible to hematological and histological alterations. It must be emphasized that, in intensive farming system, when parasites are present in high numbers and the water quality is not under control, hematological changes may lead to significant health impairment, as the suggested slight anemia herein observed, which may favor secondary infections and compromising the fish productivity.

\section{Acknowledgements}

The authors thank CNPq (National Council of Scientific and Technological Development) for financial support (CNPq 577657/2008-9) and grant to M.L. Martins (CNPq 302493/2010-7) and CAPES for scholarship sandwich to G.T. Jerônimo (BEX 9655-11-5)

\section{References}

ARAÚJO, CSO., TAVARES-DIAS, M., GOMES, ALS., ANDRADE, SMS., LEMOS, JRG., OLIVEIRA, AT., CRUZ, WR. and AFFONSO, EG., 2009. Infecções parasitárias e parâmetros sanguíneos em Arapaima gigas Schinz, 1822 (Arapaimidae) cultivados no estado do Amazonas, Brasil. In TAVARES-DIAS, M. (Eds.). Manejo e Sanidade de Peixes em Cultivo. Macapá: Embrapa Macapá. p. 389-424. CD-ROM.

BOEGER, WA., HUSAK, WS. and MARTINS, ML., 1995. Neotropical monogenoidea. 25. Anacanthorus penilabiatus n. sp. (Dactylogyridae, Anacanthorinae) from Piaractus mesopotamicus (Osteichthyes, Serrasalmidae), cultivated in the State of São Paulo, Brazil. Memórias do Instituto Oswaldo Cruz, vol. 90, no. 6, p. 699-701. http://dx.doi.org/10.1590/S0074-02761995000600008.
BUCHMANN, K. and LINDENSTRØM, T., 2002. Interactions between monogenean parasites and their fish hosts. International Journal for Parasitology, vol. 32, no. 3, p. 309-319. http://dx.doi. org/10.1016/S0020-7519(01)00332-0. PMid:11835971

BUSH, AO., LAFFERTY, KD., LOTZ, JM. and SHOSTAK, AW., 1997. Parasitology meets ecology on its own terms: Margolis et al. revisited. Journal of Parasitology, vol. 83, no. 4, p. 575-583. http://dx.doi.org/10.2307/3284227. PMid:9267395

$<$ report>Brasil. Ministério da Pesca e Aquicultura - MPA, 2010. Boletim Estatístico da Pesca e Aquicultura: Brasil 2010. Brasília. $128 \mathrm{p} .</$ report $>$

CHAVES, IS., LUVIZZOTTO-SANTOS, R., SAMPAIO, LAN., BIANCHINI, A. and MARTÍNEZ, PE., 2006. Immune adaptive response induced by Bicotylophora trachinoti (Monogenea: Diclidophoridae) infestation in pompano Trachinotus marginatus (Perciformes: Carangidae). Fish \& Shellfish Immunology, vol. 21, no. 3, p. 242-250. http://dx.doi.org/10.1016/j.fsi.2005.11.011. PMid:16483796

COLLIER, HB., 1944. Standardizations of blood haemoglobin determinations. Canadian Medical Association Journal, vol. 50, no. 6, p. 550-552. PMid:20323122.

DEL RIO-ZARAGOZA, OB., FAJER-AVILA, EJ. and ALMAZÁNRUEDA, P., 2010. Haematological and Gill responses to an experimental infection of dactylogyrid monogeneans on the spotted rose snapper Lutjanus guttatus (Steindachner, 1869). Aquaculture and Research, vol. 41, no. 11, p. 1592-1601. http:// dx.doi.org/10.1111/j.1365-2109.2009.02471.x.

GOLDENFARB, PB., BOWYER, FP., HALL, E. and BROSIOUS, E., 1971. Reproducibility in the hematology laboratory: the microhematocrit determination. American Journal of Clinical Pathology, vol. 56, no. 1, p. 35-39. PMid:5556212.

HIRAZAWA, N., TAKANO, R., HAGIWARA, H., NOGUCHI, M. and NARITA, M., 2010. The influence of different water temperatures on Neobenedenia girellae (Monogenea) infection, parasite growth, egg production and emerging second generation on amberjack Seriola dumerili (Carangidae) and the histopathological effect of this parasite on fish skin. Aquaculture (Amsterdam, Netherlands), vol. 299, no. 1-4, p. 2-7. http://dx.doi.org/10.1016/j. aquaculture.2009.11.025.

ISHIKAWA, MM., PÁDUA, SB., SATAKE, F., PIETRO, PS. and HISANO, H., 2010. Procedimentos básicos para colheita de sangue em peixes. Dourados: Embrapa Agropecuária Oeste. 8 p. Circular Técnica, 17.

JERÔNIMO, GT., SPECK, GM. and MARTINS, ML., 2010. First report of Enterogyrus cichlidarum Paperna 1963 (Monogenoidea: Ancyrocephalidae) on Nile tilapia Oreochromis niloticus cultured in Brazil. Neotropical Helminthology, vol. 4, no. 1, p. 75-80.

JERÔNIMO, GT., SPECK, GM., CECHINEL, MM., GONÇALVES, ELT. and MARTINS, ML., 2011. Seasonal variation on the ectoparasitic communities of Nile tilapia cultured in three regions in southern Brazil. Revista Brasileira de Biologia = Brazilian Journal of Biology, vol. 71, no. 2, p. 365-373. http://dx.doi. org/10.1590/S1519-69842011000300005. PMid:21755153

KHAN, RA., 2009. Parasites causing disease in wild and cultured fish in Newfoundland. Icelandic Agricultural Sciences, vol. 22, p. 29-35.

KRITSKY, DC., BOEGER, WA. and POPAZOGLO, F., 1995. Neotropical Monogenoidea. 22. Variation in Scleroductus species (Gyrodactylidea, Gyrodactylidae) from siluriform fishes of 
southeastern. Journal of Helminthological Society of Washington, vol. 62 , no. 1 , p. 53-65.

KRKOSEK, M., LEWIS, MA., MORTON, A., FRAZER, LN. and VOLPE, JP., 2006. Epizootics of wild fish induced by farm fish. Proceedings of the National Academy of Sciences of the United States of America, vol. 103, no. 42, p. 15506-15510. http://dx.doi. org/10.1073/pnas.0603525103. PMid:17021017

LIZAMA, MAP., TAKEMOTO, RM., RANZANI-PAIVA, MJT., AYROZA, LMS. and PAVANELLI, GC., 2007. Host-parasite relationship of fishes from fish farm in Assis region, São Paulo State, Brazil. 2. Piaractus mesopotamicus (Holmberg, 1887). Acta Scientiarum Biological Science, vol. 29, no. 4, p. 437-445.

MARTINS, ML., ONAKA, EM., MORAES, FR., BOZZO, FR., MELLO, A., PAIVA, FC. and GONÇALVES, A., 2002. Recent studies on parasitic infections of freshwater cultivated fish in the State of São Paulo, Brazil. Acta Scientiarum, vol. 24, no. 4, p. 981-985.

SATAKE, F., PÁDUA, SB. and ISHIKAWA, MM.,2009. Distúrbios morfológicos em células sanguíneas de peixes em cultivo: uma ferramenta prognóstica. In TAVARES-DIAS, M. (Ed.). Manejo e sanidade de peixes em cultivo. Macapá: Embrapa Macapá. p. 330-345. CD-ROM.

SCHALCH, SH. and MORAES, FR., 2005. [Seasonal distribution of gill parasites in fishes from fee-fishing at Guariba, São Paulo State, Brazil]. Revista Brasileira de Parasitologia Veterinária, vol. 14, no. 4, p. 141-146. PMid:16445870.

SCHALCH, S.H.C., MORAES, J R.E. and MOARES, F.R., 2006. Parasitic fauna of cultivated fishes in fee fishing farm of
Guariba, São Paulo State, Brazil. Acta Scientiarum Biological Science, vol. 28, no. 3, p. 291-297.

TAVARES-DIAS, M. and MORAES, FR., 2006. Hematological parameters for the Brycon orbignyanus Valenciennes, 1850 (Osteichthyes, Characidae) intensively bred. Hidrobiologica, vol. 16 , no. 3 , p. 271-274.

TAVARES-DIAS, M., MORAES, FR. and MARTINS, ML. 2008. Hematological assessment in four Brazilian teleost fish with parasitic infections, collected in feefishing from Franca, São Paulo, Brazil. Boletim do Instituto de Pesca, vol. 34, no. 2, 189-196.

TAVARES-DIAS, M., MORAES, FR., MARTINS, ML. and KRONKA, SN., 2001. Parasitic fauna of cultivated fishes in fee fishing farm of Franca, State of São Paulo, Brazil. II. Metazoans. Brazilian Journal of Zoology, vol. 18, no. 1, p. 81-95.

WINTROBE, MM., 1934. Variations in the size and hemoglobin content of erythrocytes in the blood of various vertebrates. Folia Haematological, vol. 51, no. 32, p. 32-49.

XU, D-H., SHOEMAKER, CA. and KLESIUS, PH., 2007. Evaluation of the link between gyrodactylosis and streptococcosis of Nile tilapia, Oreochromis niloticus (L.). Journal of Fish Diseases, vol. 30, no. 4, p. 233-238. http://dx.doi.org/10.1111/j.13652761.2007.00806.x. PMid:17394525

ZANIBONI-FILHO, E., 2004. Piscicultura das espécies nativas de água doce. In POLI, CR., POLI, ATB., ANDREATTA, E. and BELTRAME, E. (Eds.). Aquicultura: experiências brasileiras. Florianópolis: Multitarefa. p. 337-368. 